\title{
Prospective Comparison of Loop Excision under Colposcopic Guidance versus Vitom Guidance
}

\author{
Prospektiver Vergleich der Schlingenkonisation (LEEP) \\ unter kolposkopischer versus VITOM-Kontrolle
}

Authors

Affiliations
G. F. Vercellino ${ }^{1}$, V. Chiantera ${ }^{1}$, J. Gaßmann ${ }^{2}$, E. Erdemoglu ${ }^{3}$, I. Drechsler ${ }^{1}$, S. Frangini ${ }^{1}$, A. Schneider ${ }^{1}$, G. Böhmer ${ }^{4}$

${ }^{1}$ Klinik für Gynäkologie, Charité, Berlin

${ }^{2}$ Abteilung für Klinische Psychologie und Psychotherapie, Georg-Elias-Müller Institut für Psychologie, Göttingen

${ }^{3}$ Department of Gynecology, Suleyman Demirel University, Isparta, Turkey

${ }^{4}$ Colposcopy Clinic Wagner Stibbe, Bad Münder
Key words

- cervical cancer

- cervical intraepithelial neoplasia (CIN)

- cervical precancerous condition

Schlüsselwörter

- Zervix

- Zervixkarzinom

- Zervixpräkanzerose

\section{received 13.4.2012 \\ revised $\quad 19.8 .2012$ \\ accepted $\quad 31.8 .2012$}

\section{Bibliography}

Dol http://dx.doi.org/

10.1055/s-0032-1327779

Published online 23.10.2012

Geburtsh Frauenheilk 2012; 72:

945-948 @ Georg Thieme

Verlag KG Stuttgart · New York

ISSN 0016-5751

Correspondence

Dr. Evrim Erdemoglu,

MD, Assoc. Prof.

Suleyman Demirel University

Department of Gynaecology

Cunur, Isparta

32260 Isparta

Turkey

evrimmd@yahoo.com

\section{Abstract}

$\nabla$

Background: Aim of the study was to compare the quality of loop excision using a colposcope with results using the VITOM system. Results compared included cervical volume removed, intra- and postoperative complications, and positive resection margins.

Methods: A total of 200 patients with histologically confirmed high-grade cervical premalignant lesions, persistent atypical cytological results and/or suspicious colposcopic findings, and cytological and histological discrepancies were included in the study. In transformation zone type 1 (T1) only a superficial cone biopsy was done, in zones type 2 and 3 (T2 and T3) a superficial outside cone biopsy or a deeper inside cone biopsy were done respectively, followed by endocervical curettage. Volume of removed tissue, complications, and positive resection margins were compared for the colposcopy and the VITOM groups.

Findings: Demographic and reproductive features were similar between groups. In the VITOM group $49 \%$ of patients had zone T1, 30\% had zone $\mathrm{T} 2$, and $21 \%$ had zone T3. In the group of patients managed by colposcopy, 48,45 , and $7 \%$ of patients had zone T1, T2 and T3 zone, respectively $(p<0.01)$. A "top hat" procedure was done in 65\% of patients in the VITOM group and in $38 \%$ of patients in the colposcopy group $(p<0.05)$. Mean volume of removed cervical tissue measured was similar, with $1.2 \mathrm{~cm}^{3}$ measured in the VITOM group and $1.14 \mathrm{~cm}^{3}$ in the colposcopy group $(p>0.05)$. There were no significant differences in the type of procedure or the mean volume of removed tissue. Results were similar for both groups with respect to positive resection margins and complications.

Conclusion: VITOM is a safe and reliable system. Results using the VITOM system are comparable to those obtained with conventional colposcopy.

\section{Zusammenfassung \\ $\nabla$}

Hintergrund: Ziel der Studie war, die Qualität von Schlingenkonisationen (Loop Excision) unter kolposkopischer Sicht mit denen unter Vergrößerung mit dem VITOM ${ }^{\circledR}$-System zu vergleichen. Die Zielvariablen waren das Volumen des Resektats, intra- und postoperative Komplikationen sowie der Anteil der positiven Resektionsränder.

Methoden: 200 Patientinnen wurden in die Studie eingeschlossen. Einschlusskriterien waren histologisch gesicherte CIN II/III, persistierend positive Abstriche, diskrepante Befunde zwischen Zytologie und Histologie und hochsuspekte kolposkopische Befunde. Bei TZ1-Transformationszone (TZ) wurde ein flaches Resektat entfernt, bei TZ2 und TZ3 wurde je nach Befund ein zweites, endozervikales Resektat entnommen. Abschließend wurde bei allen Patientinnen eine endozervikale Abrasio durchgeführt. Das Volumen des Resektats, Komplikationen sowie der Anteil der Non-in-sano-Situationen wurden zwischen dem kolposkopischen Verfahren und dem VI$\mathrm{TOM}^{\circledR}$-System verglichen.

Ergebnisse: Demografische und Kinderwunschdaten waren vergleichbar. In der VITOM ${ }^{\circledR}$-Gruppe hatten $49 \%$ eine TZ1-, 30\% eine TZ2- und $21 \%$ eine TZ3-Zone, entsprechend zeigten in der Kolposkopiegruppe $48 \%$ eine TZ1, 45\% eine TZ2 und 7\% eine TZ3 $(p<0,01)$. Bei $65 \%$ der Patientinnen in der VITOM $^{\circledR}$-Gruppe und 38\% der KolposkopieGruppe wurde ein endozervikales Resektat entnommen $(\mathrm{p}<0,05)$. Das durchschnittliche Volumen der Resektate, das mittels der ArchimedesVolumetrie ermittelt wurden, war mit 1,2 ccm in der VITOM ${ }^{\circledR}$-Gruppe direkt vergleichbar mit dem durchschnittlichen Volumen $\left(1,14 \mathrm{~cm}^{3}\right)$ in der Kolposkopiegruppe ( $p>0,05)$. Die Ergebnisse bez. der Resektionsränder sowie Komplikationen waren gleich.

Fazit: Die Therapie von CIN-Läsionen mit dem VI$\mathrm{TOM}^{\circledR}{ }^{\circledR}$-System ist sicher und reproduzierbar. Die 
The potential advantage of VITOM is the broader availability of endoscopic systems in the operating theatre.

\section{Introduction}

\section{$\nabla$}

Loop electrosurgical excision procedure (LEEP) is a common procedure to treat and manage high-grade cervical premalignant lesions (CIN II-III). LEEP is done using a colposcope. Tissue resection using magnification allows resection to be done with sound margins and with preservation of healthy tissue as a prerequisite for maintaining the reproductive function of the cervix. Although magnified assisted loop excision is an ideal choice for patients who wish to have children, it is not the standard surgical approach [1-5]. We previously reported on our initial experience using a novel highdefinition (HD) video exoscopic system $\left(\right.$ VITOM $\left.^{\circledR}\right)$ consisting of a laparoscope, an HD camera, high-quality optics, and a light source to evaluate premalignant lesions in the lower genital tract under magnification and discussed the system's accuracy and good correlation to histological findings in high-grade lesions [6].

To offer the majority of women with high-grade cervical intraepithelial neoplasias (CIN) tissue-preserving surgery, we want to integrate the VITOM ${ }^{\circledR}$ system in daily practice. Most gynaecologists who perform conisations are also experienced in laparoscopy and have a laparoscopic surgical unit available. In contrast, colposcopes are not installed in the majority of operating theatres in Germany. The use of laparoscopic equipment for conisation procedures could improve the quality of conisations and, thus, be beneficial for women's health.

We prospectively studied whether VITOM ${ }^{\circledR}$ could be used in the operating theatre for conisation procedures and LEEP. The primary aim of our study was to compare the quality of loop excisions using a colposcope and those done using the VITOM ${ }^{\circledR}$ system with respect to cervical volumes removed, intra- and postoperative complications, and positive resections margins.

\section{Methods}

\section{Participants}

Women referred to the Charité Cervix Centre, Charité University, Berlin, Germany and to the Colposcopy Clinic Wagner Stibbe, Bad Münder, Germany, between July 2010 and April 2011 were prospectively included into the study. Patient age ranged from 18 to 80 years old, and patients were included irrespective of any history of previous cervical surgeries or pregnancy. All patients had histologically confirmed CIN II-III, persistent atypical cytological results and/or suspicious colposcopic findings, and cytological and histological discrepancies. Exclusion criteria were previous or current neoplasia, radiotherapy of the pelvis, severe concomitant internal disease, psychiatric disease, HIV infection, and drug usage. 100 patients were prospectively recruited in the Charité Cervix Cancer Centre, Charité University, Berlin, Germany, and underwent LEEP excision under VITOM ${ }^{\circledR}$ guidance; another 100 patients prospectively recruited in the Colposcopy Clinic Wagner Stibbe, Bad Münder, Germany underwent LEEP excision under colposcopic guidance. Recruitment took place between July 2010 and April 2011 in both centres, and written consent to the study was obtained for every patient at the time of the first visit and prior to the excision procedure.
Ergebnisse sind mit der klassischen kolposkopischen Methode, die den Goldstandard darstellt, vergleichbar. Ein möglicher Vorteile von VITOM ${ }^{\circledR}$ ist die größere Verfügbarkeit von endoskopischen Systemen in OP-Bereichen.

Both centres used a common prospective study protocol which was approved by the institutional review board of Charité University.

\section{Measurement}

In transformation zone (TZ) type 1 (T1) only a superficial cone biopsy was performed. A "top hat" LEEP is a procedure that involves two loop excisions: a conventional superficial LEEP followed by a second excision of the residual endocervix using a smaller-diameter loop. In TZ type 2 or 3 (T2 and T3) a superficial outside cone biopsy and a deeper inside cone biopsy (top hat procedure) were performed, followed by endocervical curettage. The volume of removed tissue was measured by volumetry based on the Archimedes principle. We estimated that volumes of removed tissue ranged from 0.5 to $1.5 \mathrm{~cm}^{3}$. A rough estimate thus assumed a mean of $1.0 \mathrm{~cm}^{3}$ with a standard variation of $0.25 \mathrm{~cm}^{3}$. Assuming a dispersion of $0.25 \mathrm{~cm}^{3}$, the mean removed volume could be determined with a precision of \pm 0.05 (half the length of the bilateral $95 \% \mathrm{CI}$ ) with a total number of 100 patients in each group.

\section{Procedures}

We used a Carl Zeiss colposcope with a magnification of between $4 \times$ to $20 \times$ and a green filter. Video exocolposcopy was done with the VITOM ${ }^{\circledR}$ system, consisting of the VITOM ${ }^{\circledR}$ scope, xenon light source, HD camera system, AIDA HD documentation system, 1 monitor, and mechanical support arm (all Karl Storz, Tuttlingen, Germany). The 3-chip HD camera head has a resolution of $1920 \times 1080$ pixels (full HD, progressive scan) and a frame rate of 50 frames oz. Camera images are displayed on the 26-inch HD monitor. Luminance of the monitor is $400 \mathrm{~cd} / \mathrm{m}^{2}$. The optic is held by a mechanical holding arm. Documentation was done using the AIDA HD documentation system.

A Graves speculum was inserted to expose the vagina and cervix, and a smoke plume evacuator was used in all operations. Magnification was provided during all procedures either by the colposcope or the VITOM system. First, the cervix was inspected after application of $5 \%$ acetic acid and 3\% iodine solution. The working distance of the colposcope is about $30 \mathrm{~cm}$ from the surgical site, while the operating range of the VITOM ${ }^{\circledR}$ varies from 30 to $60 \mathrm{~cm}$. An electrosurgical generator (Erbe, Tuttlingen, Germany) and cutting loops with diameters between 5 and $25 \mathrm{~mm}$ were used.

\section{Statistical analysis}

Descriptive statistics were used to assess the frequencies in samples. Univariate analysis of categorical variables was done using the chi-square test $\left(\mathrm{x}^{2}\right)$ or Fisher's exact test to test for significance of association of frequency data. It was also used to analyse whether the distribution between categories of one variable was independent of the distribution between categories of the other, i.e., to assess the differences in frequencies between categorical variables. Differences between the two groups (VITOM ${ }^{\circledR}$ vs. Colposcopy) were compared using used t-tests.

All statistical analyses were performed using PASW 18 (Predictive Analytics Software, SPSS Inc., Chicago, IL, USA). The level of significance was set at $\mathrm{p} \leq 0.05$. 
Table 1 Comparison of frequency, percentages and significance between the VITOM and colposcopy groups.

\begin{tabular}{|lccl|} 
& $\begin{array}{l}\text { VITOM } \\
\mathbf{n}(\%)\end{array}$ & $\begin{array}{l}\text { Colposcopy } \\
\mathbf{n}(\%)\end{array}$ & $\mathbf{p}$ \\
\hline Menopausal & $12(12 \%)$ & $2(2 \%)$ & $>0.05$ \\
\hline Wish to have a child & $76(76 \%)$ & $77(77 \%)$ & $>0.05$ \\
\hline $\begin{array}{l}\text { Previous surgery } \\
\text { Intraoperative }\end{array}$ & $6(6 \%)$ & $0(0 \%)$ & $>0.05$ \\
complications & $1(1 \%)$ & $0(0 \%)$ & $>0.05$ \\
\hline Late complications & $2(2 \%)$ & $0(0 \%)$ & $>0.05$ \\
\hline R1 resection & $12(12 \%)$ & $8(8 \%)$ & $>0.05$ \\
\hline T1/T2/T3 & $49 / 30 / 21$ & $48 / 45 / 7$ & $<0.01$ \\
\hline
\end{tabular}

\section{Results}

A total of 200 women were included in the present study. In the VITOM $^{\circledR}$ group, 62 patients had histologically confirmed CIN IIIII, 34 patients had persistent positive cytology and/or suspicious colposcopy findings, 2 patients had persistent CIN I, and 2 patients had contact bleeding: the latter patients explicitly requested conisation. In the colposcopy group 70 patients had histologically confirmed CIN II-III, 30 patients had persistent positive cytology and/or suspicious colposcopy findings.

Mean age of patients in the VITOM $^{\circledR}$ group was 34.7 years (range: 18-60 years), and 33.3 years (range: $18-72$ years) in the colposcopy group. In the VITOM $^{\circledR}$ group 88 patients were premenopausal and 12 were postmenopausal; 76 patients wished to have children. In the colposcopy group 98 patients were premenopausal and 2 postmenopausal: 77 patients wished to have children. One patient in the VITOM ${ }^{\circledR}$ group was pregnant and 6 had a history of previous cervical surgery (either conisation or trachelectomy). In the colposcopy group no patient had undergone previous surgery and no patient was pregnant ( Table 1 ).

In the VITOM $^{\circledR}$ group the squamocolumnar junction (SCJ) was visible in 49 patients, partly visible in 30 patients, and not visible in 21 patients. In the colposcopy group the SCJ was fully visible in 48 patients, partly visible in 45 and not visible in 7 patients. A pregnant patient in the $\mathrm{VITOM}^{\circledR}$ group had strong bleeding intraoperatively. Two patients in the VITOM $^{\circledR}$ group had bleeding 2 weeks postoperatively. Eleven patients in the VITOM ${ }^{\circledR}$ group had positive margins. There were no complications in the colposcopy group; resection margins were positive in 8 patients.

A "top hat" procedure was performed in $65 \%$ of patients of the VITOM $^{\circledR}$ group and in $38 \%$ of patients in the colposcopy group $(p<0.05)$. However, mean removed cervical volumes were similar in both groups, with $1.2 \mathrm{~cm}^{3}$ in the VITOM $^{\circledR}$ group and $1.14 \mathrm{~cm}^{3}$ in the colposcopy group $(\mathrm{p}>0.05)$. There were no significant differences between the type of procedure and the mean volume of tissue removed ( Table 2 ).

Table 2 Comparison of mean and standard deviation and significance.

\begin{tabular}{|lccc}
\hline Variable & VITOM $^{\circledR}$ & $\begin{array}{l}\text { Colposcopy } \\
\text { Mean (SD) }\end{array}$ & Mean (SD) \\
& $34.7( \pm 9.9)$ & $33.3( \pm 7.6)$ & $>0.05$ \\
\hline Age & $1.2( \pm 0.8)$ & $1.14( \pm 0.6)$ & $>0.05$
\end{tabular}

\section{Discussion}

$\nabla$

We compared the quality of excisions of cervical premalignant disease under magnification done using a colposcope with those done using the VITOM ${ }^{\circledR}$ system with respect to intra- and postoperative complications, positive resection margins, and cervical volume of removed tissue. The study populations in both groups were similar, however there was a significantly larger number of T3 zones in the VITOM ${ }^{\circledR}$ group (21\% of patients vs. $7 \%$ in the colposcopy group), probably due to the fact that a higher number of women in this group were menopausal and they had also had previous surgery of the cervix uteri. This difference could theoretically have led to a not negligible difference between VITOM ${ }^{\circledR}$ and colposcopy findings with regard to their ability to evaluate cervical lesions. Exocolposcopy with the VITOM ${ }^{\circledR}$ system is accurate and shows a good correlation with histological findings in high-grade cervical disease [6], hence we assumed that this difference did not cause any real bias in the evaluation of cervical lesions during surgery.

This difference in T3 zones between the two groups could also explain the different rates of "top hat" procedures in the two groups (65\% of patients in the VITOM $^{\circledR}$ group vs. $38 \%$ in the colposcopy group). The volume of removed cervical tissue was similar in the two groups: $1.2 \mathrm{~cm}^{3}$ in the VITOM ${ }^{\circledR}$ group vs. $1.14 \mathrm{~cm}^{3}$ in the colposcopy group. However, since the etiopathogenesis of preterm birth after excisional cervical procedure for CIN II-III is not known but the rate is increased compared to the general population, a possible negative role cannot be ruled out. Use of an additional loop excision can also inhibit pathological evaluation of the resected specimen; however in our series, the number of positive margins was similar for both groups. Resection margin positivity is a significant prognostic factor for recurrence after LEEP. Rates of positive resection margins are reported to be between 11$30 \%$ and between $40-80 \%$ for squamous dysplasia and adenocarcinoma, respectively [7]. The rate of positive or thermally altered cervical margins varies widely in different series, with a reported average rate of $15 \%$ [8-10]. In our study, positive margins were found in 8 and 12\% of patients in the colposcopy and VITOM groups, respectively $(p>0.05)$. However, VITOM and colposcopy procedures were performed in different clinics, which might introduce a bias.

Historically, excisional cervical procedures are not performed with colposcopic assistance in Germany, even though Professor Hinselmann, the inventor of the colposcope, was a German. According to unpublished data from major German health insurance companies, around $50 \%$ of excisional cervical procedures are done on an outpatient basis in private practices. The majority of these doctors do not use any kind of magnifying aid during the surgery.

Rates of both intra- and postoperative LEEP complications do not vary much between the different studies reported [11]. The perioperative rate of complications is reported to be $7-11 \%$ [12]. In our study, the perioperative complication rate was lower than that in the literature. There was one case of intraoperative bleeding and 2 cases of postoperative bleeding. In the literature, the rates of intraoperative and late postoperative bleeding are given as 3.4 and $4.9 \%$, respectively [13]. Although the complication rate did not differ significantly between the study groups, the complication rate was higher in the VITOM group. This may be due to the higher rate of "top hat" procedures and of pregnancy in the VITOM group [12]. 
As the colposcope is nothing more than an operating microscope, the question could arise whether there is any real advantage of using the VITOM $^{\circledR}$ system, or whether it is just one more piece of equipment in the operating room? We do not suggest any changes to state-of-the-art excisional cervical procedures for CIN II-III: we consider the colposcope to be an excellent tool in experienced hands. Surgeons familiar with colposcope-guided excisional procedures for CIN II-III should not turn to other techniques and abandon their expertise. However, we support use of the VITOM $^{\circledR}$ system for the still large number of gynaecologists who still perform this procedure without magnification aids. The majority of gynaecologists have a laparoscopic unit, and in these cases addition of the VITOM $^{\circledR}$ system would be very easy. Moreover, the VITOM $^{\circledR}$ system has a very short learning curve since gynaecologists are trained to perform laparoscopic surgery and are used to translating two-dimensional data into three-dimensional anatomical structures, making implementation of the system unproblematic in daily practice.

This could lead to a reduction in the volume of healthy cervical tissue removed unnecessarily in young women with CIN II-III wishing to have children, and result in an improvement of women's health. Further randomized controlled studies are needed to evaluate the use of VITOM ${ }^{\circledR}$ guided exocolposcopy to achieve better obstetrical outcomes in women undergoing excisional therapy for cervical premalignant lesions.

\section{Conflict of Interest}

None.

\section{References}

1 Oyesanya OA, Amerasinghe C, Manning EA. A comparison between loop diathermy conization and cold-knife conization for management of cervical dysplasia associated with unsatisfactory colposcopy. Gynecol Oncol 1993; 50: 84-88

2 Alvarez RD, Helm CW, Edwards RP et al. Prospective randomized trial of LLETZ versus laser ablation in patients with cervical intraepithelial neoplasia. Gynecol Oncol 1994; 52: 175-179

3 Duggan BD, Felix JC, Muderspach LI et al. Cold-knife conization versus conization by the loop electrosurgical excision procedure: a randomized, prospective study. Am J Obstet Gynecol 1999; 180: 276-282

4 Prendiville W, Cullimore J, Norman S. Large loop excision of the transformation zone (LLETZ). A new method of management for women with cervical intraepithelial neoplasia. Br J Obstet Gynaecol 1989; 96: 1054-1060

5 Bigrigg MA, Codling BW, Pearson P et al. Colposcopic diagnosis and treatment of cervical dysplasia at a single clinic visit. Experience of low-voltage diathermy loop in 1000 patients. Lancet 1990; 336: 229231

6 Vercellino GF, Erdemoglu E, Kyeyamwa S et al. Evaluation of the VITOM in digital high-definition video exocolposcopy. J Low Genit Tract Dis 2011; 15: 292-295

7 Keijser KG, Kenemans P, van der Zanden PH et al. Diathermy loop excision in the management of cervical intraepithelial neoplasia: diagnosis and treatment in one procedure. Am J Obstet Gynecol 1992; 166: $1281-1287$

8 Chappatte OA, Byrne DL, Raju KS et al. Histological differences between colposcopic-directed biopsy and loop excision of the transformation zone (LETZ): a cause for concern. Gynecol Oncol 1991; 43: 46-50

9 Howe DT, Vincenti AC. Is large loop excision of the transformation zone (LLETZ) more accurate than colposcopically directed punch biopsy in the diagnosis of cervical intraepithelial neoplasia? Br J Obstet Gynaecol 1991; 98: 588-591

10 Paraskevaidis E, Koliopoulos G, Lolis E et al. Delivery outcomes following loop electrosurgical excision procedure for microinvasive (FIGO stage IA1) cervical cancer. Gynecol Oncol 2002; 86: 10-13

11 Brun JL, Youbi A, Hocké C. [Complications, sequellae and outcome of cervical conizations: evaluation of three surgical techniques].J Gynecol Obstet Biol Reprod (Paris) 2002; 31: 558-564

12 Kietpeerakool C, Suprasert P, Khunamornpong $S$ et al. "Top hat" versus conventional loop electrosurgical excision procedure in women with a type 3 transformation zone. Int J Gynaecol Obstet 2010; 109: 59-62

13 Sutthichon P, Kietpeerakool C. Perioperative complications of an outpatient loop electrosurgical excision procedure: a review of 857 consecutive cases. Asian Pac J Cancer Prev 2009; 10: 351-354 